\title{
Biochemical Evaluation of the Effects of Hydroxyurea in Vitro on Red Blood Cells
}

\author{
Cristiane Oliveira Renó ${ }^{1}$, Grazielle Aparecida Silva Maia ${ }^{1}$, Leilismara Sousa Nogueira ${ }^{1}$, \\ Melina de Barros Pinheiro ${ }^{2}$, Danyelle Romana Alves Rios ${ }^{3}$, Vanessa Faria Cortes ${ }^{1} \oplus$, \\ Leandro Augusto de Oliveira Barbosa ${ }^{1}$ and Hérica de Lima Santos ${ }^{1, *}$
}

Citation: Renó, C.O.; Maia, G.A.S.; Nogueira, L.S.; de Barros Pinheiro, M.; Rios, D.R.A.; Cortes, V.F.; de Oliveira Barbosa, L.A.; de Lima Santos, H. Biochemical Evaluation of the Effects of Hydroxyurea in Vitro on Red Blood Cells. Antioxidants 2021, 10, 1599. https://doi.org/10.3390/ antiox10101599

Academic Editors: Soliman Khatib, Dana Atrahimovich Blatt and Alessandra Napolitano

Received: 5 August 2021

Accepted: 28 September 2021

Published: 12 October 2021

Publisher's Note: MDPI stays neutral with regard to jurisdictional claims in published maps and institutional affiliations.

Copyright: (c) 2021 by the authors. Licensee MDPI, Basel, Switzerland. This article is an open access article distributed under the terms and conditions of the Creative Commons Attribution (CC BY) license (https:/ / creativecommons.org/licenses/by/ $4.0 /)$.
1 Laboratório de Bioquímica Celular, Campus Centro Oeste Dona Lindu, Universidade Federal de São João del-Rei, Divinópolis 35501-296, Minas Gerais, Brazil; cristianereno@outlook.pt (C.O.R.); graquimica@ufsj.edu.br (G.A.S.M.); leilismara@ufsj.edu.br (L.S.N.); cortesvf@ufsj.edu.br (V.F.C.); lbarbosa@ufsj.edu.br (L.A.d.O.B.)

2 Laboratório de Análises Clínicas, Campus Centro Oeste Dona Lindu, Universidade Federal de São João del-Rei, Divinópolis 35501-296, Minas Gerais, Brazil; melinapinheiro@ufsj.edu.br

3 Laboratório de Hematologia Clínica, Campus Centro Oeste Dona Lindu, Universidade Federal de São João del-Rei, Divinópolis 35501-296, Minas Gerais, Brazil; danyelleromana@ufsj.edu.br

* Correspondence: hlima@ufsj.edu.br; Tel.: +55-37-4690-4552 or +55-37-4690-4550

\begin{abstract}
Hydroxyurea (HU) is a low-cost, low-toxicity drug that is often used in diseases, such as sickle cell anemia and different types of cancer. Its effects on the red blood cells (RBC) are still not fully understood. The in vitro effects of $\mathrm{HU}$ were evaluated on the biochemical parameters of the RBC from healthy individuals that were treated with $0.6 \mathrm{mM}$ or $0.8 \mathrm{mM} \mathrm{HU}$ for $30 \mathrm{~min}$ and $1 \mathrm{~h}$. After $30 \mathrm{~min}$, there was a significant increase in almost all of the parameters analyzed in the two concentrations of $\mathrm{HU}$, except for the pyruvate kinase (PK) activity. A treatment with $0.8 \mathrm{mM} \mathrm{HU}$ for $1 \mathrm{~h}$ resulted in a reduction of the levels of lipid peroxidation, $\mathrm{Fe}^{3+}$, and in the activities of some of the enzymes, such as glutathione reductase (GR), glucose-6-phosphate dehydrogenase (G6PD), and PK. After the incubation for $1 \mathrm{~h}$, the levels of $\mathrm{H}_{2} \mathrm{O}_{2}$, lipid peroxidation, reduced glutathione (GSH), enzymatic activity (hexokinase, G6PD, and superoxide dismutase (SOD) were reduced with the treatment of $0.8 \mathrm{mM} \mathrm{HU}$ when compared with $0.6 \mathrm{mM}$. The results have suggested that a treatment with $\mathrm{HU}$ at a concentration of $0.8 \mathrm{mM}$ seemed to be more efficient in protecting against the free radicals, as well as in treating diseases, such as sickle cell anemia. HU appears to preferentially stimulate the pentose pathway over the glycolytic pathway. Although this study was carried out with the RBC from healthy individuals, the changes described in this study may help to elucidate the mechanisms of action of HU when administered for therapeutic purposes.
\end{abstract}

Keywords: hydroxyurea; red blood cells; energy metabolism; antioxidant system; reactive oxygen species

\section{Introduction}

Hydroxyurea $(\mathrm{HU})$ is the main drug of choice for the treatment of sickle cell anemia (SCA) and it provides therapeutic benefits through its multiple mechanisms of action. It is easily synthesized by urea hydroxylation and acts by inhibiting an enzyme that is involved in the synthesis of ribonucleic acid. In addition to HU being used to treat hematological diseases, such as chronic myeloid leukemia, and its ability to generate nitric oxide, a potent vasodilator, also helps to relieve the patients' pain [1-3]. HU acts on the bone marrow and due to its cytotoxic effects, it decreases the production of blood cells. Furthermore, it stimulates the increase in the synthesis of $\mathrm{HbF}$, which contributes to the reduction of painful crises and vaso-occlusive processes [2].

The drug is administered in different doses, which differ according to the patient and the disease to be treated. In SCA, the doses range from $15-35 \mathrm{mg} / \mathrm{kg} /$ day, and in resistant 
chronic myeloid leukemia (CML) from 1000-2000 mg/day. This drug is inexpensive. It is administered as a single agent and orally. Based on currently available data, the HU treatment fulfills the criteria established for SCA and it should be offered much more frequently $[1,2,4]$. The absorption of $\mathrm{HU}$ is fast and it occurs in the intestine, with wide body distribution $[2,5,6]$ and maximum plasma doses, ranging between $0.2 \mathrm{mM}$ and $0.8 \mathrm{mM}$, depending on the dose to which the patient is submitted [7].

Despite being widely used for many years, the effects of $\mathrm{HU}$ on human RBC have not been fully clarified. Some studies have linked the use of $\mathrm{HU}$ to the oxidation of hemoglobin, with increased lipid peroxidation in the membrane of these cells $[8,9]$.

The main physiological role of the RBC is the transport of gases $\left(\mathrm{O}_{2}, \mathrm{CO}_{2}\right)$ from the lungs to the tissues and vice versa, in addition to maintaining the systemic acid/base balance. They have important antioxidant systems, which contribute substantially to their functions and integrity. The damage of RBC integrity, as well as to their membranes, has been shown to contribute significantly to serious pathologies [10-12].

Owing to the importance of the RBC, particularly due to their great carrier potential for drug delivery, it is necessary to broaden the understanding of the HU actions in these cells under non-pathological conditions. This knowledge may be applied to diseases in which $\mathrm{HU}$ is included in pharmacotherapeutic protocols. In this context, the authors have aimed to describe the effects of $\mathrm{HU}$ in the RBC by evaluating some aspects that are related to the membrane profile, the energy metabolism, and the antioxidant system.

\section{Materials and Methods}

\subsection{Ethics Statement}

The present research project was approved by the Ethics Committee on Human Research of the Federal University of São João del Rei, Brazil ( $n^{\circ}$ 2.977.566). All of the enrolled subjects signed an informative consent form.

\subsection{Study Samples}

This study included six volunteer and healthy adults aged between 24 and 35 years old, of both genders, who were selected from the community of the Federal University of São João del-Rei, Brazil. As the aim has been to evaluate the effect of hydroxyurea on healthy erythrocytes and not characterize its biological effect, the number of samples was small, but this is common practice in similar experiments [13-15]. All of the participants were healthy. This was confirmed by self-reported normal blood tests and an absence of hemoglobin S, in addition to no clinical symptoms. The exclusion criteria were a personal, or a family history of vascular disease, coagulopathies, anemia, the use of daily medications, or current or recent pregnancy. Thirty $\mathrm{mL}$ venous blood samples were collected after $8-12 \mathrm{~h}$ of fasting when using EDTA as an anticoagulant and were transported between 2 and $8{ }^{\circ} \mathrm{C}$. These were equally distributed into three groups, including (1) control (with no HU), (2) addition of $0.6 \mathrm{M} \mathrm{HU}$, and (3) addition of $0.8 \mathrm{M} \mathrm{HU}$. All of the samples were analyzed at 30 and $60 \mathrm{~min}$ after adding HU. The concentrations chosen above were based on the therapeutic regimen of $\mathrm{HU}$, which was adopted for patients with vaso-occlusive crises, that is, $15-35 \mathrm{mg} / \mathrm{kg}$ and a plasma peak of between $0.2-0.8 \mathrm{mM}$ [7]. During the incubation period, the samples were kept at $4{ }^{\circ} \mathrm{C}$ and after this, the red blood cells concentrate was separated by centrifugation at $700 \times g$ and at $4{ }^{\circ} \mathrm{C}$ for $10 \mathrm{~min}$ when using a CT18000R $\left(\right.$ Cientec ${ }^{\circledR}$ ) centrifuge (Belo Horizonte, MG, Brazil). The supernatant of each sample was removed, aliquoted, and stored in a freezer at $-20^{\circ} \mathrm{C}$ until required.

\subsection{Preparation of Hemolysate}

All of the RBC concentrates were subjected to three successive washes, then doubling the initial sample volume with $0.9 \% \mathrm{NaCl}$ solution, and centrifuging for $10 \mathrm{~min}$ at $700 \times g$. After the last wash, each pellet of RBC was lysed, in the proportion of 1:20 when using a hemolysis solution containing $0.27 \mathrm{M}$ EDTA and $0.007 \mathrm{mM} \beta$ mercaptoethanol. This 
was then frozen in acetone in a freezer at $-20^{\circ} \mathrm{C}$. The hemolysate was thawed at room temperature and kept on ice for further enzymatic analyses.

\subsection{Determination of the Hemoglobin $(\mathrm{Hb})$ Concentration}

The determination of the $\mathrm{Hb}$ concentration in the hemolysates and plasma was performed by the Cyanomethemoglobin Method, which was adapted from Dacie and Lewis [16], accessed on 6 March 2019 when using Drabkin's solution (0.9 mM potassium ferricyanide and $1.5 \mathrm{mM}$ potassium cyanide), as well as a hemoglobin standard of known concentration $(10 \mathrm{~g} / \mathrm{dL})$. The reading was performed by scanning on a GENESYS ${ }^{\mathrm{TM}}$ $10 \mathrm{UV} /$ Vis spectrophotometer (Thermo Scientific ${ }^{\circledR}$, Waltham, MA, USA), at $540 \mathrm{~nm}$ for $5 \mathrm{~min}$. The $\mathrm{Hb}$ concentrations of the samples were calculated by using the calibration factor that was obtained by the absorbance of the $\mathrm{Hb}$ standard.

\subsection{Oxidative Stress Indicators}

\subsubsection{Lipid Peroxidation}

To investigate lipid peroxidation, the plasma levels of the thiobarbituric acid reactive substances (TBARS) were determined. For this, $100 \mu \mathrm{L}$ of plasma was added to a tube containing $1 \mathrm{~mL}$ of a solution that was made with $15 \%$ trichloroacetic acid, $0.38 \%$ thiobarbituric acid, and $0.25 \mathrm{~N}$ hydrochloric acid. The mixture was incubated at $100{ }^{\circ} \mathrm{C}$ for $30 \mathrm{~min}$ and then centrifuged at $3000 \mathrm{rpm}$ for $10 \mathrm{~min}$. The optical density (OD) was measured at $535 \mathrm{~nm}$ when using a GENESYS ${ }^{\mathrm{TM}}$ S10 UV/Vis spectrophotometer (Thermo Scientific ${ }^{\circledR}$, Waltham, MA, USA). The malondialdehyde (MDA) content was determined by using a standard curve that was constructed in a concentration range of 1 to $100 \mathrm{nM}[17,18]$.

\subsubsection{Determination of $\mathrm{Fe}^{3+}$ in the Residual Plasma Samples}

The $\mathrm{Fe}^{3+}$ quantification was performed as described by Adams [19], with slight modifications. In a test tube, $150 \mu \mathrm{L}$ of plasma was mixed with $1.5 \mathrm{~mL}$ of $1 \mathrm{M} \mathrm{KSCN}$, and the volume was adjusted to $3.0 \mathrm{~mL}$ with $0.9 \% \mathrm{NaCl}$. The samples were then homogenized using Vortex Multifuncional K40-1020 (KASVI ${ }^{\circledR}$, São José dos Pinhais, PR, Brazil), and the optical density was read at $480 \mathrm{~nm}$ (OD480) by using GENESYS ${ }^{\mathrm{TM}} 10 \mathrm{UV} /$ Vis spectrophotometer (Thermo Scientific ${ }^{\circledR}$, Waltham, MA, USA). A standard curve was constructed when using a $1 \mathrm{M} \mathrm{FeCl}_{3}$ solution as a standard. The OD was stable for $15 \mathrm{~min}$.

\subsubsection{Quantification of Hydrogen Peroxide $\left(\mathrm{H}_{2} \mathrm{O}_{2}\right)$}

The quantification of the $\mathrm{H}_{2} \mathrm{O}_{2}$ production was performed by adding $20 \mu \mathrm{L}$ of hemolysate to a reaction medium containing $250 \mu \mathrm{M}$ of ammoniacal ferrous sulfate, $25 \mathrm{mM}$ of $\mathrm{H}_{2} \mathrm{SO}_{4}$, and $100 \mu \mathrm{M}$ of xylenol orange in a $1 \mathrm{~mL}$ Eppendorf ${ }^{\circledR}$ tube. After vortexing for $10 \mathrm{~s}$, the tube was at rest and protected from the light for $45 \mathrm{~min}$, and then the product formed was read on a GENESYS ${ }^{\mathrm{TM}} 10 \mathrm{UV} /$ Vis scanning spectrophotometer (Thermo Scientific ${ }^{\circledR}$, Waltham, MA, USA) at a wavelength of $580 \mathrm{~nm}$ [20]. The production of $\mathrm{H}_{2} \mathrm{O}_{2}$ was calculated from a standard curve by using hydrogen peroxide pure $\left(\mathrm{H}_{2} \mathrm{O}_{2}\right)$ in concentrations from 0 to $100 \mathrm{nM}$.

\subsubsection{Determination of the Superoxide Dismutase (SOD) Activity}

The SOD activity was determined through a method that was adopted in the authors' laboratory when using epinephrine in an alkaline medium since it is converted into adrenochrome, producing $\mathrm{O}^{-2}$, which is a SOD substrate. The SOD activity was defined by assessing its ability to inhibit epinephrine oxidation. The $100 \%$ oxidation was defined in a tube containing a medium, with glycine $(50 \mathrm{mM}, \mathrm{pH} 10)$ and $25 \mu \mathrm{L}$ of epinephrine $(60 \mathrm{mM} \mathrm{pH}=2)$. The other tubes contained the same medium but with different volumes of hemolysate $(2-6 \mu \mathrm{L})$. The oxidation reaction was measured and the OD of each condition was read at $480 \mathrm{~nm}$ on a GENESYS ${ }^{\mathrm{TM}} 10 \mathrm{UV} /$ Vis scanning spectrophotometer (Thermo Scientific ${ }^{\circledR}$, Waltham, MA, USA). The enzyme activity was expressed in units required to inhibit $50 \%$ of the rate of the adrenochrome formation [21]. 


\subsubsection{Determination of the Catalase Activity}

The catalase activity was determined in RBC hemolysates and was based on the method of Aebi [22], with some modifications. Immediately before determining the activity of this enzyme, the hemolysate was again centrifuged and the supernatant was used for this purpose. Twenty (20) $\mu \mathrm{L}$ of this hemolysate supernatant was added to a cuvette containing $2 \mathrm{~mL}$ of $50 \mathrm{mM}$ phosphate buffer ( $\mathrm{pH}$ 7.0). The reactions were initiated by the addition of $3.4 \mu \mathrm{L}$ of freshly prepared $30 \% \mathrm{H}_{2} \mathrm{O}_{2}$. The decomposition of $\mathrm{H}_{2} \mathrm{O}_{2}$ was followed spectrophotometrically at $240 \mathrm{~nm}$, using a GENESYS ${ }^{\mathrm{TM}} 10 \mathrm{UV} / \mathrm{Vis}$ scanning spectrophotometer (Thermo Scientific ${ }^{\circledR}$, Waltham, MA, USA). The activity was estimated from the slope and expressed as micromoles of $\mathrm{H}_{2} \mathrm{O}_{2}$ decomposed per minute.

\subsubsection{Determination of the Enzymatic Activity of Glutathione Peroxidase (GPx)}

The GPx activity was determined by following the oxidation of NADPH when using hydrogen peroxide at a wavelength of $340 \mathrm{~nm}$. The Flohe and collaborators [23] and the Nakamura and Hosada [24] methods were adapted by using a reaction medium, with a $50 \mathrm{mM}$ phosphate buffer, $4 \mathrm{mM}$ EDTA, $1 \mathrm{mM} \mathrm{GSH}, 1.25 \mathrm{mM} \mathrm{NaN}_{3}, 0.16 \mathrm{mM} \mathrm{NADPH}$, and $5 \mu \mathrm{L}$ of hemolysate. The total volume was adjusted to $1 \mathrm{~mL}$ with water. The reaction was initiated by the addition of $4 \mathrm{mM} \mathrm{H}_{2} \mathrm{O}_{2}$. Modifications in the $\mathrm{OD}$ at $340 \mathrm{~nm}$ were observed within $2 \mathrm{~min}$. The enzyme activity was measured at nmol NADPH· $\min ^{-1} \cdot \mathrm{L} / \mathrm{gHb}[23,24]$.

\subsubsection{Determination of the Content of Reduced Glutathione (GSH)}

The GSH concentration was evaluated by adding $5 \mu \mathrm{L}$ of hemolysate to a reaction medium containing $0.1 \mathrm{M}$ phosphate buffer ( $\mathrm{pH}$ 8.0) and DNTB/EDTA $10 \mathrm{mM}$. After $15 \mathrm{~min}$ at room temperature, the solution was read by a GENESYS ${ }^{\mathrm{TM}} 10 \mathrm{UV} /$ Vis scanning spectrophotometer (Thermo Scientific ${ }^{\circledR}$, Waltham, MA, USA) at a wavelength of $412 \mathrm{~nm}$. The GSH concentration was measured by performing a standard curve (correction factor) at $\mathrm{nmolGSH} \cdot \mathrm{L} / \mathrm{gHb}[25,26]$.

\subsubsection{Determination of the Glutathione Reductase (GR) Activity}

The GR activity was determined by following the method as described by Racker and collaborators [27], with adaptations. The reaction medium that was used contained a phosphate buffer at $\mathrm{pH} 7.6,50 \mathrm{mM}$ EDTA, $0.4 \mathrm{mM}, 0.1 \mathrm{mM} \mathrm{NADPH}, 50 \mu \mathrm{L}$ of hemolysate, and $1 \mathrm{mM}$ glutathione disulfide (GSSG). The volume was completed with distilled water to $1 \mathrm{~mL}$, and the absorbance of the mixture was read by a GENESYS ${ }^{\mathrm{TM}} 10 \mathrm{UV} /$ Vis scanning spectrophotometer (Thermo Scientific ${ }^{\circledR}$, Waltham, MA, USA) at a wavelength of $340 \mathrm{~nm}$ for $2 \mathrm{~min}$. The enzyme activity was measured at $\rho \mathrm{mol} \mathrm{NADPH} \cdot \mathrm{min}^{-1} \cdot \mathrm{L} / \mathrm{gHb}$ [27].

\subsection{Energy Metabolism of the $R B C$}

2.6.1. Determination of the Glucose-6-Phosphate Dehydrogenase (G6PD) Activity

The G6PD activity was measured by incubating $20 \mu \mathrm{L}$ of hemolysate at $37^{\circ} \mathrm{C}$ for $10 \mathrm{~min}$ in a reaction medium containing a buffer $(0.1 \mathrm{M}$ Tris- $\mathrm{HCl}$ and $0.5 \mathrm{mM}$ EDTA, at $\mathrm{pH} 8.0)$, $0.01 \mathrm{M} \mathrm{MgCl}_{2}, 0.2 \mathrm{mM}$ NADP, and $0.6 \mathrm{mM}$ glucose-6-phosphate. The absorbance was measured in a GENESYS ${ }^{\text {TM }} 10$ UV/Vis spectrophotometer (Thermo Scientific ${ }^{\circledR}$, Waltham, MA, USA) at $340 \mathrm{~nm}$, and its variation per minute was evaluated, with and without the substrate (glucose-6-phosphate). The enzyme activity was quantified by reducing $\mathrm{NADP}^{+}$ to NADPH. The enzymatic activity was calculated at $\mathrm{Ul} \cdot \mathrm{gHb}^{-1} \cdot \mathrm{min}^{-1}$, where $\mathrm{U}$ was equal to $1 \mu \mathrm{mol} \mathrm{NADP} \cdot \mathrm{min}^{-1} \cdot \mathrm{mL}^{-1}[28]$.

\subsubsection{Determination of the Hexokinase Activity (HEX)}

The HEX activity was determined by using $50 \mu \mathrm{L}$ of hemolysate in a reaction medium containing a buffer (0.1 M Tris- $\mathrm{HCl}$ and $0.5 \mathrm{mM}$ EDTA, at $\mathrm{pH}=8.0), 0.01 \mathrm{M} \mathrm{MgCl}_{2}, 0.2 \mathrm{mM}$ NADP, $2 \mathrm{mM}$ glucose, $2 \mathrm{mM}$ of ATP, and 0.1 of a unit of glucose- 6 -phosphate dehydrogenase enzyme. The absorbance was measured in a GENESYS ${ }^{\mathrm{TM}} 10 \mathrm{UV} /$ Vis spectrophotometer (Thermo Scientific ${ }^{\circledR}$, Waltham, MA, USA) at $340 \mathrm{~nm}$, and its variation per minute was 
evaluated, with and without ATP. The enzyme activity was quantified by the reduction of $\mathrm{NADP}^{+}$to NADPH. The enzymatic activity was calculated at $\mathrm{Ul} \cdot \mathrm{gHb}^{-1} \cdot \mathrm{min}^{-1}$, where $\mathrm{U}$ was equal to $1 \mu \mathrm{mol}$ of $\mathrm{NADP}^{+} \cdot \mathrm{min}^{-1} \cdot \mathrm{mL}^{-1}[28]$.

\subsubsection{Determination of the Pyruvate Kinase (PK) Activity}

The PK activity was determined by incubating $20 \mu \mathrm{L}$ of hemolysate at $37^{\circ} \mathrm{C}$ for $10 \mathrm{~min}$ in a reaction medium containing a buffer $(0.1 \mathrm{M}$ Tris- $\mathrm{HCl}$ and $0.5 \mathrm{mM}$ EDTA, at $\mathrm{pH}=8.0)$, $0.01 \mathrm{M} \mathrm{MgCl}_{2}, 0.1 \mathrm{M} \mathrm{KCl}, 0.2 \mathrm{mM} \mathrm{NADH}, 1.5 \mathrm{mM}$ ADP, 6 units of lactate dehydrogenase enzyme, and $5 \mathrm{mM}$ phosphoenolpyruvate (PEP). The absorbance was measured in a GENESYS ${ }^{\mathrm{TM}} 10 \mathrm{UV} /$ Vis spectrophotometer (Thermo Scientific ${ }^{\circledR}$, Waltham, MA, USA) at $340 \mathrm{~nm}$, and its variation per minute was evaluated, with and without PEP. The enzyme activity was quantified by the oxidation of NADPH to NADP ${ }^{+}$. The enzymatic activity was calculated at $\mathrm{Ul} \cdot \mathrm{gHb}^{-1} \cdot \mathrm{min}^{-1}$, where $\mathrm{U}$ was equal to $1 \mu \mathrm{mol}$ of $\mathrm{NADP}^{+} \cdot \mathrm{min}^{-1} \cdot \mathrm{mL}^{-1}$ [28].

\subsection{Statistical Analysis}

The results were analyzed when using GraphPad Prism 5 software. For the analysis of data normality, the Shapiro-Wilk test (for any sample size) was used. For the data with a normal distribution, the Analysis of Variance (ANOVA) was used, followed by Tukey's multiple comparison test. Values of $p<0.05$ were considered significant.

\section{Results}

\subsection{Determination of the Oxidative Stress Indicators}

Biological markers, such as $\mathrm{Fe}^{3+}, \mathrm{MDA}$, and $\mathrm{H}_{2} \mathrm{O}_{2}$ are frequently used to predict oxidative stress in the RBC. During a 30-min treatment, it was possible to observe a profile increase of these indicators in the treated groups when compared to the control group, as described below. Figure 1 illustrates that the exposure of the RBC to concentrations of 0.6 and $0.8 \mathrm{mM}$ of $\mathrm{HU}$ resulted in an increase in plasma $\mathrm{Fe}^{3+}$ of about $39.9 \%$ and $28.6 \%$, respectively, compared to the control group (Figure 1A) $(p<0.05)$. Figure $1 \mathrm{~B}$ depicts the evaluation of lipid peroxidation when using the TBARS method. The MDA content increased by $52 \%$ in the $\mathrm{HU}$-treated group at a concentration of $0.8 \mathrm{mM}(p<0.05) . \mathrm{H}_{2} \mathrm{O}_{2}$ was also measured because of its ability to react and damage the RBC membrane. When evaluating the total $\mathrm{H}_{2} \mathrm{O}_{2}$ content in the hemolysate, a significant increase of $25 \%$ and $28 \%$ were found in the concentrations of $0.6 \mathrm{mM}$ and $0.8 \mathrm{mM}$, respectively (Figure 1C).

The authors also examined whether the alterations in the oxidative stress indicators were time-dependent. After an hour of incubation with $0.8 \mathrm{mM} \mathrm{HU}$, it was observed that the $\mathrm{Fe}^{3+}$ content was $20 \%$ lower $(p<0.05)$ when compared with the control groups (Figure $2 \mathrm{~A}$ ). A significant decrease of $47 \%(p<0.05)$ in the MDA content in the plasma that was treated with $0.8 \mathrm{mM} \mathrm{HU}$ was also found when compared with the control groups. When comparing the groups that were treated with HU ( $60 \mathrm{~min}$ ), a significant decrease $(41 \%)$ $(p<0.05)$ in the MDA was observed with the concentration of $0.8 \mathrm{mM} \mathrm{HU}$, in relation to $0.6 \mathrm{mM}$ (Figure 2B).

The hydrogen peroxide content in the hemolysate, as shown in Figure 2C, increased significantly in the treated group at both $\mathrm{HU}$ concentrations when compared to control. The increase was $15 \%,(p<0.001)$ and $7 \%$ at concentrations of $0.6 \mathrm{mM}$ and $0.8 \mathrm{mM}$ $(p<0.05)$, respectively. A significant decrease of $7 \%(p<0.05)$ in the $\mathrm{H}_{2} \mathrm{O}_{2}$ was also observed in the sample of hemolysate that was treated with $0.8 \mathrm{mM}$ when compared to that treated with $0.6 \mathrm{mM}$ (Figure 2C). 
A

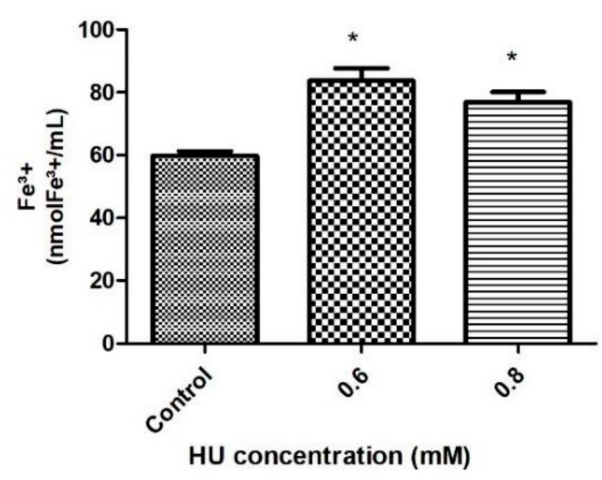

B

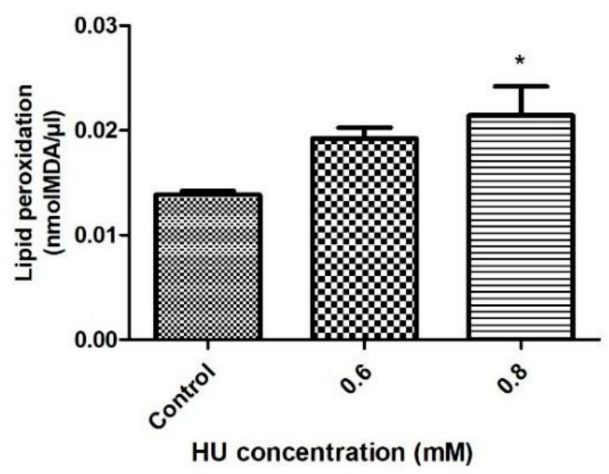

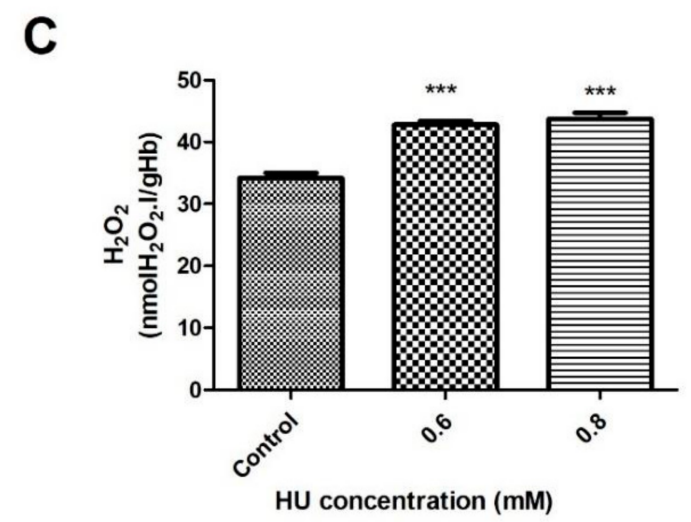

Figure 1. Oxidative stress indicators in the erythrocytes of the control samples that were treated with 0.6 and $0.8 \mathrm{mM} \mathrm{HU}$ $(n=3)$ for 30 min. (A) $\mathrm{Fe}^{3+}$ was measured in plasma; (B) Lipid peroxidation (MDA) was measured in plasma; (C) Hydrogen peroxide $\left(\mathrm{H}_{2} \mathrm{O}_{2}\right)$ was measured in hemolysate. In all of the cases, ${ }^{*}$ represents a comparison between the controls and the treated groups $\left(^{*} p<0.05\right.$ and $\left.{ }^{* * *} p<0.001\right)$.

\subsection{Antioxidant Defense of the RBC}

As reported previously, oxidation is a possible mechanism of damage to the RBC, together with the enzymes of the antioxidant system, such as CAT, SOD, GPx, and GR, which act as protectors of these cells against attack by the reactive species. The possible oxidative effects of $\mathrm{HU}$ on the RBC were also measured by the antioxidant enzyme activities in the treated and control samples.

When evaluating the activity of the SOD enzyme, a significant increase of about $12 \%$ was observed after $30 \mathrm{~min}$ of incubation with $\mathrm{HU}$, at both concentrations of $\mathrm{HU}$ when compared to the control group $(p<0.001)$ (Figure $3 \mathrm{~A}$ ). After $1 \mathrm{~h}$ of incubation, it was also possible to observe a significant increase $(p<0.001)$ of $13 \%$ and $8 \%$, in the concentrations of $0.6 \mathrm{mM}$ and $0.8 \mathrm{mM}$ of $\mathrm{HU}$, respectively, when compared to the control groups (Figure $4 \mathrm{~A}$ ). When comparing the two treated groups ( 30 and $60 \mathrm{~min}$ ), a significant $5 \%$ increase occurred in the $0.6 \mathrm{mM} \mathrm{HU}$ (Figure $4 \mathrm{~A}$ ). 
A

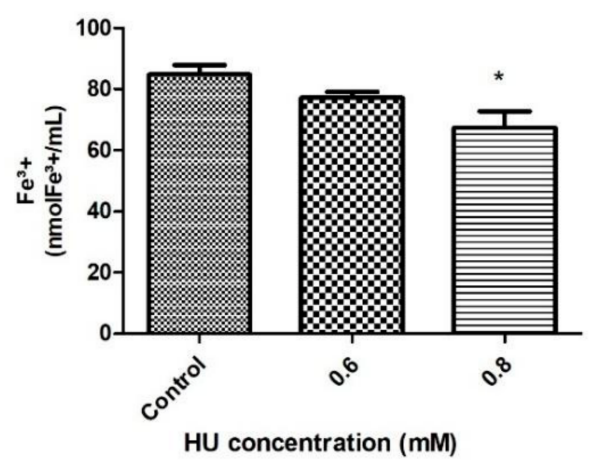

B

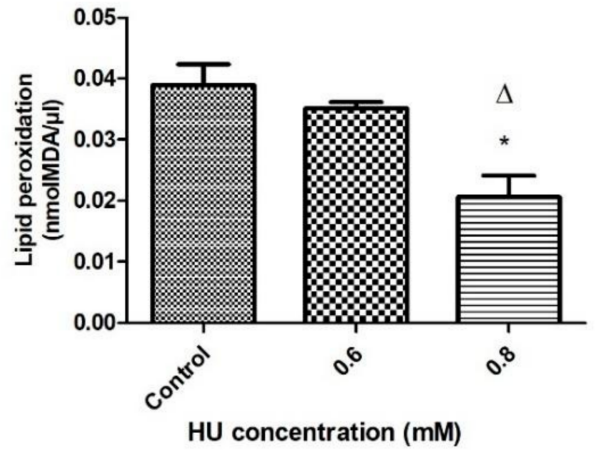

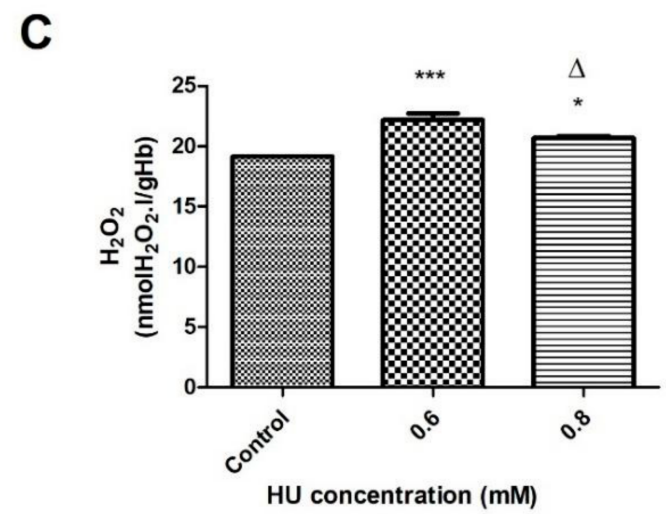

Figure 2. Oxidative stress indicators in the erythrocytes of the control samples that were treated with 0.6 and $0.8 \mathrm{mM} \mathrm{HU}(n=3)$ for $1 \mathrm{~h}$. (A) $\mathrm{Fe}^{3+}$ was measured in plasma; (B) Lipid peroxidation (MDA) was measured in plasma; $(\mathbf{C})$ Hydrogen peroxide $\left(\mathrm{H}_{2} \mathrm{O}_{2}\right)$ was measured in hemolysate. In all of the cases, ${ }^{*}$ represents a comparison between the controls and the treated groups $\left({ }^{*} p<0.05\right.$ and $* * *<0.001)$, while $\Delta$ represents a comparison between the groups treated with 0.6 and $0.8 \mathrm{mM} \mathrm{HU}$ $(p<0.05)$.

The catalase activity did not differ significantly among all of the examined groups (Figures 3B and 4B). The activity of the enzyme glutathione peroxidase showed a significant increase at both of the treatment times. The groups that were treated with HU showed an increase of $82 \%(p<0.05)(30 \mathrm{~min})$ and $15.5 \%(p<0.05)(1 \mathrm{~h})$ when compared with the control groups (Figures $3 \mathrm{C}$ and $4 \mathrm{C}$ ).

The activity of glutathione reductase in the group that was treated with $0.6 \mathrm{mM} \mathrm{HU}$ (after $30 \mathrm{~min}$ ) showed a significant increase $(p<0.05)$, which was 2 times greater when compared to the control groups (Figure 3D). The 1-h treatment presented a different profile, that is, the samples that were treated with 0.6 and $0.8 \mathrm{mM}$ of $\mathrm{HU}$ obtained a significantly lower GR activity $(p<0.05)$ of about $26 \%$ and $17 \%$, respectively, compared to the control groups (Figure 4D). The GSH content increased significantly $(p<0.05)$ in the two HU concentrations over $30 \mathrm{~min}$ at $62 \%$ and $52 \%$ in the samples that were treated with 0.6 and $0.8 \mathrm{mM}$, respectively (Figure $3 \mathrm{E}$ ). After the 1-h treatment, it was possible to observe a significant increase $(p<0.05)$ of $6 \%$ but only at a concentration of $0.6 \mathrm{mM}$, while a decrease of $6 \%(p<0.05)$ was observed in the treated group with $0.8 \mathrm{mM}$ HU when compared to the control groups (Figure 4E). At a concentration of $0.6 \mathrm{mM} \mathrm{HU}$, there was a significant increase of $12 \%(p<0.05)$ in the GSH content when compared to the sample that was treated with $0.8 \mathrm{mM} \mathrm{HU}$ (Figure 4E). 
A

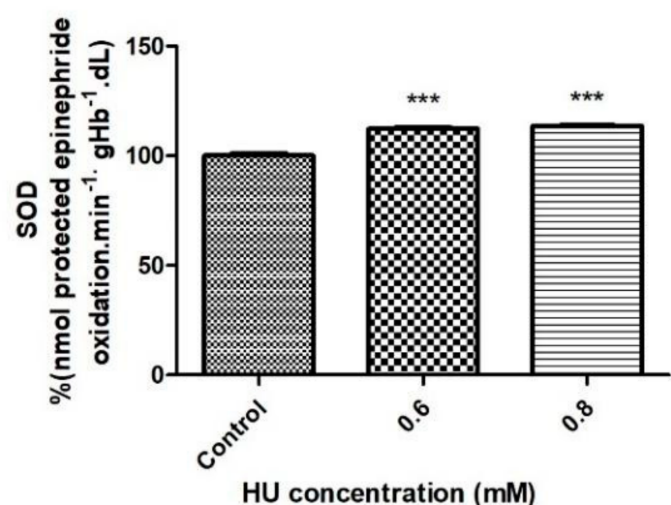

C

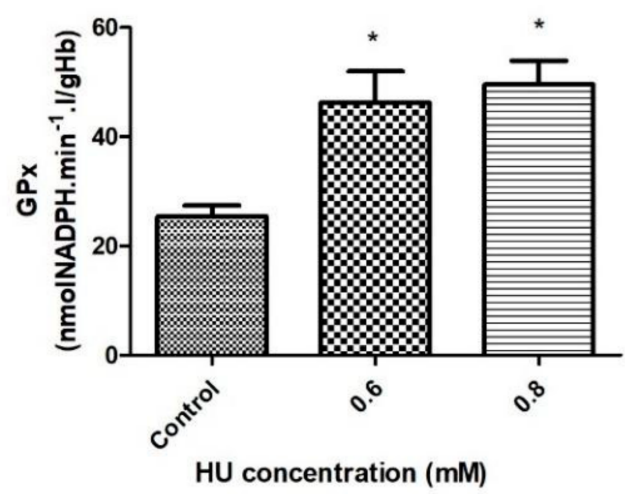

B

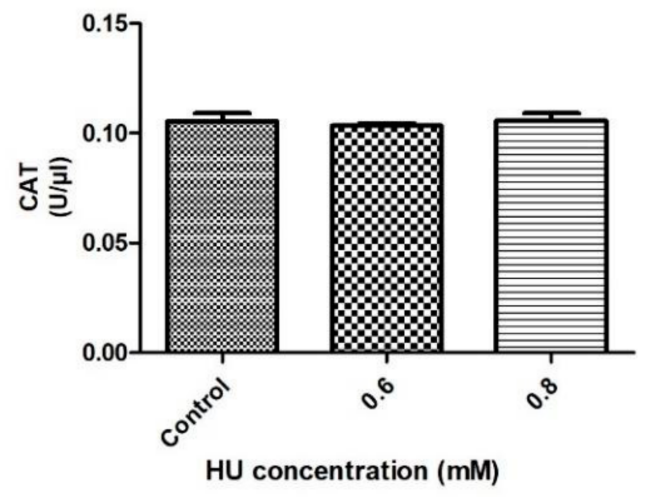

D

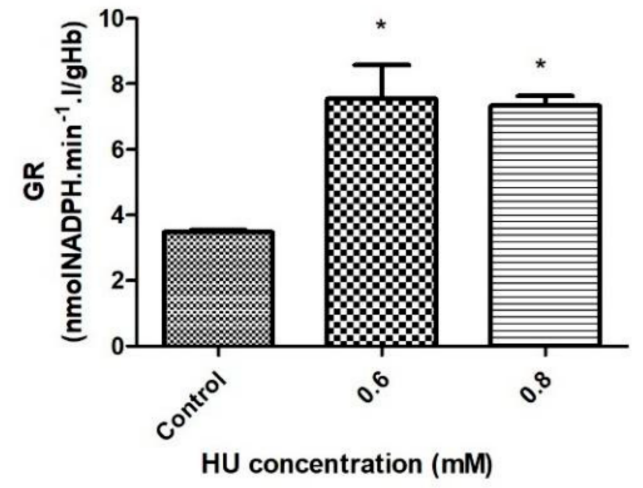

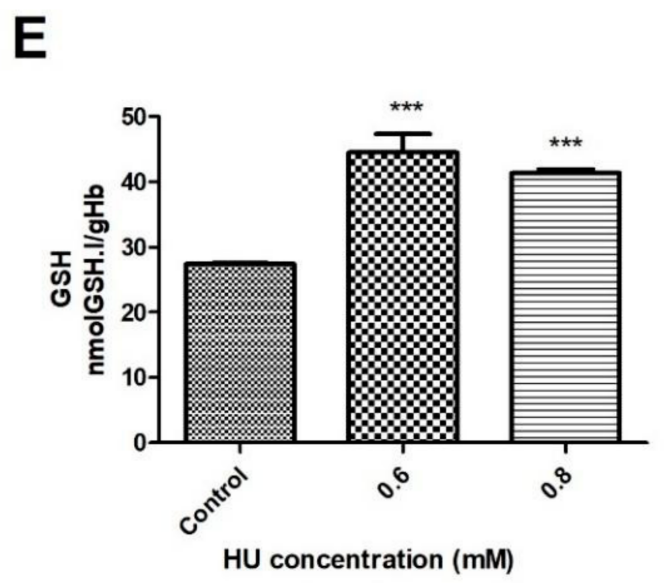

Figure 3. Enzymatic activity of the erythrocyte antioxidant system in the control samples that were treated with 0.6 and $0.8 \mathrm{mM} \mathrm{HU}(n=3)$ for $30 \mathrm{~min}$. Hemolysate was used to measure (A) Superoxide dismutase (SOD); (B) Catalase (CAT); (C) Glutathione peroxidase (GPx); (D) Glutathione reductase (GR); (E) Reduced glutathione. In all of the cases, ${ }^{*}$ it represents a comparison between the control groups and the treated groups ${ }^{*} p<0.05$ and $\left.{ }^{* * *} p<0.001\right)$. 
A

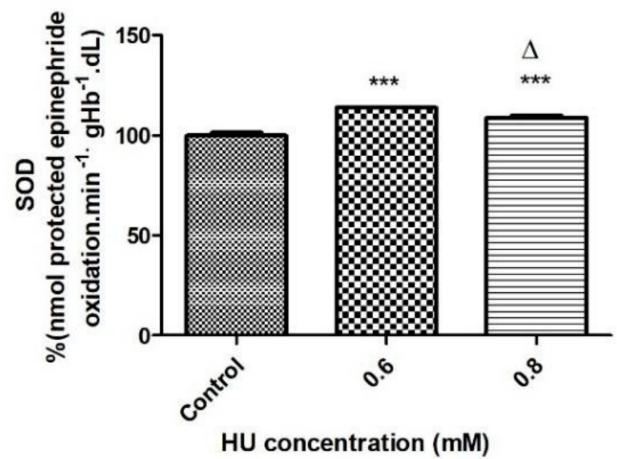

C

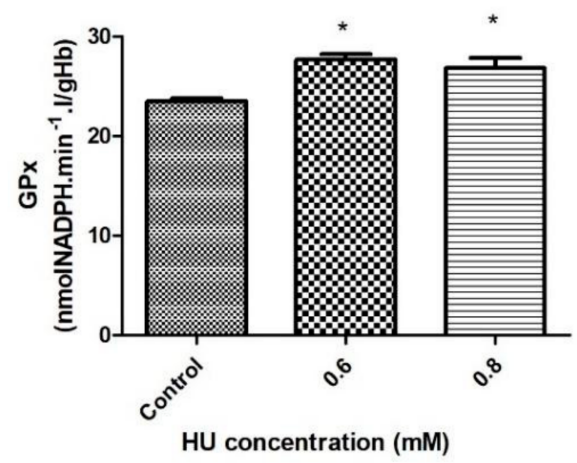

B

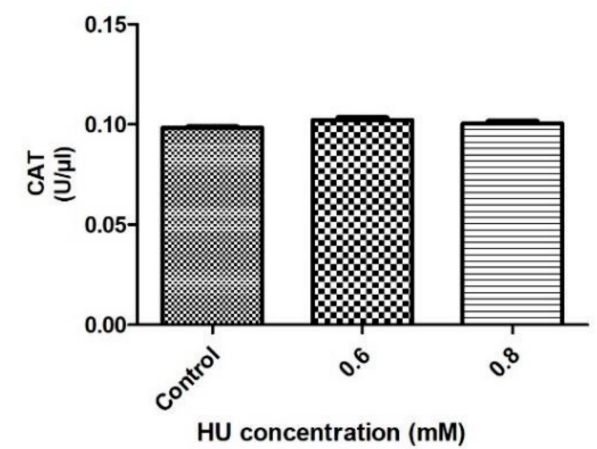

D

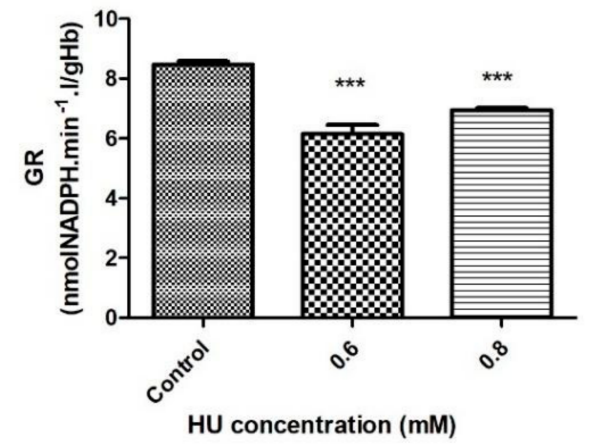

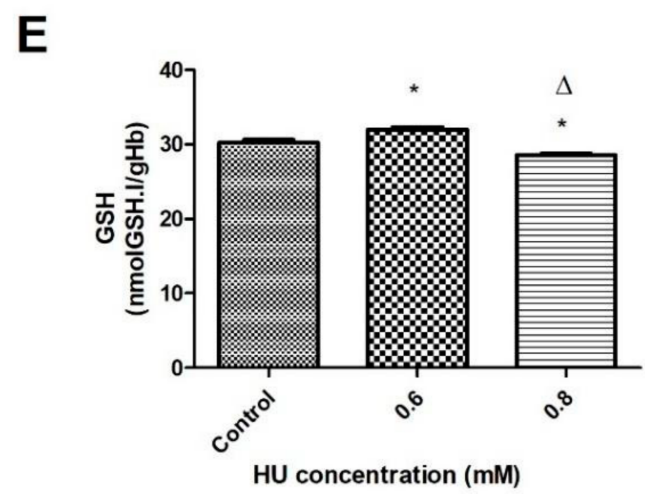

Figure 4. Enzymatic activity of the erythrocyte antioxidant system in the control samples that were treated with 0.6 and $0.8 \mathrm{mM} \mathrm{HU}(\mathrm{n}=3)$ for $1 \mathrm{~h}$. Hemolysate was used to measure (A) Superoxide dismutase (SOD); (B) Catalase (CAT); (C) Glutathione peroxidase (GPx); (D) Glutathione reductase (GR); (E) Reduced glutathione. In all of the cases, * represents a comparison between the controls and the treated groups $\left({ }^{*} p<0.05\right.$ and $\left.{ }^{* * *} p<0.001\right)$, while $\Delta$ represents a comparison between the groups that were treated with 0.6 and $0.8 \mathrm{mM} \mathrm{HU}(p<0.05)$.

\subsection{The Energy Metabolism of the RBC}

The pathway (Glucose $\rightarrow$ Glucose 6-phosphate $\rightarrow 2$ ATP +2 lactate generation) uncouples the ATP generation from the oxygen consumption and it is the only source of metabolic energy for the mature human RBC. The primary outcome revealed that with 30 min of treatment with $\mathrm{HU}$, the G6PD had a significant increase of $37.5 \%$ and $54.6 \%$ in its 
activity at concentrations of $0.6 \mathrm{mM}$ and $0.8 \mathrm{mM}$, respectively $(p<0.05)$, compared to the control groups (Figure 5A).

A

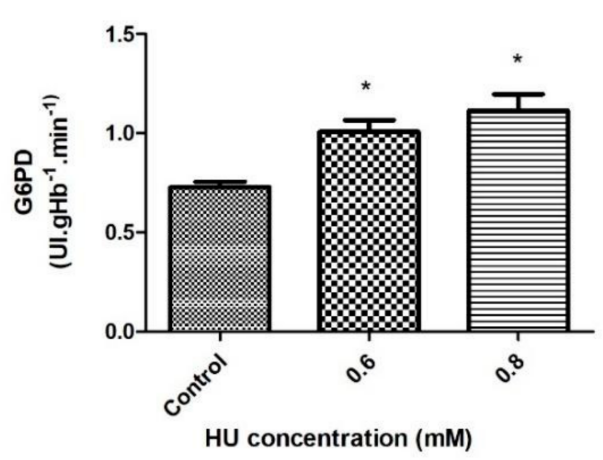

B

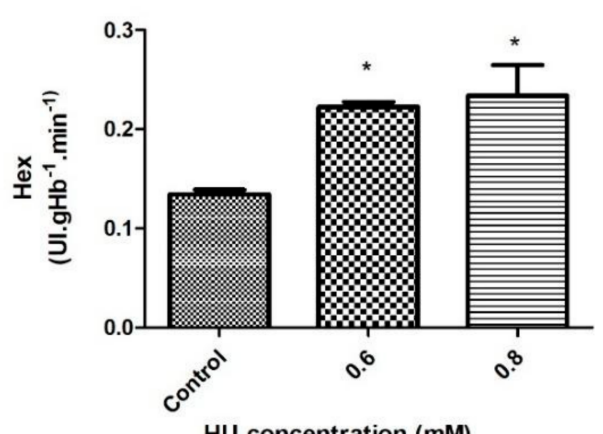

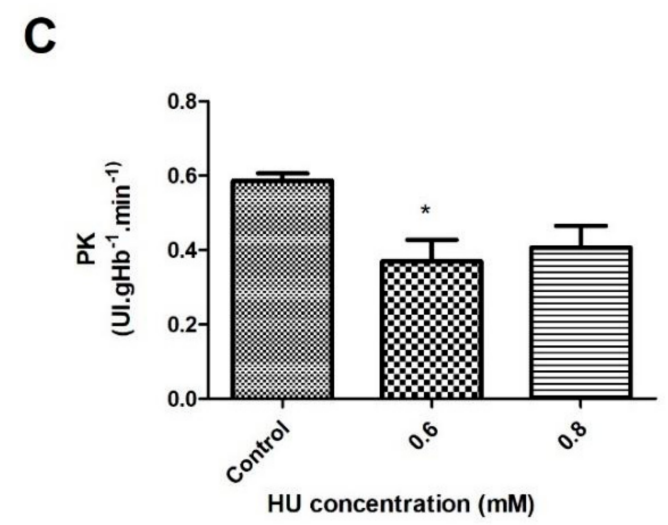

Figure 5. Enzymatic activity of the erythrocyte energy metabolism in the control samples that were treated with 0.6 and $0.8 \mathrm{mM} \mathrm{HU}(n=3)$ for $30 \mathrm{~min}$. Hemolysate was used to measure (A) Glycose-6-phosphate-dehydrogenase (G6PD); (B) Hexokinase (Hex); (C) Pyruvate kinase (PK). In all of the cases, ${ }^{*}$ represents a comparison between the control groups and the groups that were treated with $\mathrm{HU}\left({ }^{*} p<0.05\right)$.

For the 1-h treatment, a significant increase in the G6PD activity of 30\% $(p<0.001)$ was observed at a concentration of $0.6 \mathrm{mM} \mathrm{HU}$, whereas at $0.8 \mathrm{mM}$ of HU, the G6PD activity was lower by $23 \%(p<0.001)$, compared to the control groups. When analyzing both of the HU concentrations, the G6PD activity was $42 \%$ lower when comparing $0.8 \mathrm{mM}$ to $0.6 \mathrm{mM}$ of HU (Figure 6A).

The hexokinase activity in the 30-min treatment had a significant increase of around $73 \%$ at both of the HU concentrations when compared to the control groups (Figure 5B). During the 1-h treatment, it was not possible to observe significant differences between the control groups and the treated groups. There was a significant decrease of about $77 \%(p<0.05)$ in the hexokinase values of the sample that was treated with $0.8 \mathrm{mM}$, compared to that treated with $0.6 \mathrm{mM} \mathrm{HU}$ (Figure 6B).

Regarding the activity of pyruvate kinase (PK), it was possible to observe a significant reduction in the PK activity of about $23 \%(p<0.05)$ after $30 \mathrm{~min}$ of incubation with $0.6 \mathrm{mM}$ $\mathrm{HU}$ when compared to the control groups (Figure $5 \mathrm{C}$ ). Within $1 \mathrm{~h}$, a significant decrease of about $59 \%(p<0.05)$ in the PK activity was also observed at a concentration of $0.8 \mathrm{mM}$, compared with the control groups (Figure $6 \mathrm{C}$ ). To facilitate a data comparison, the results are summarized in Tables 1 and 2. 
A

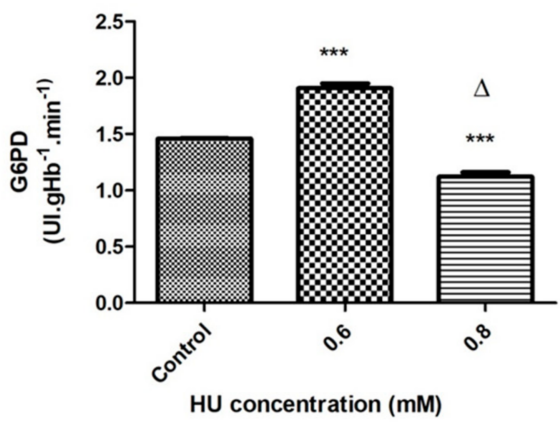

B

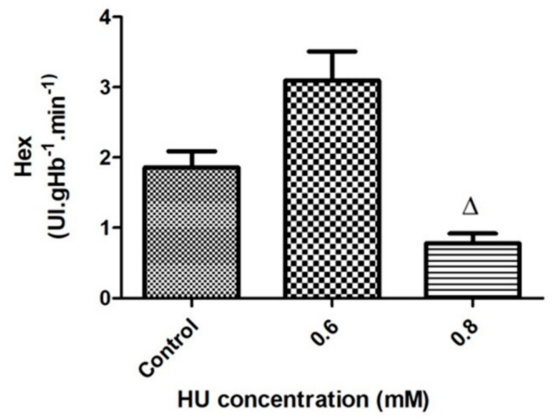

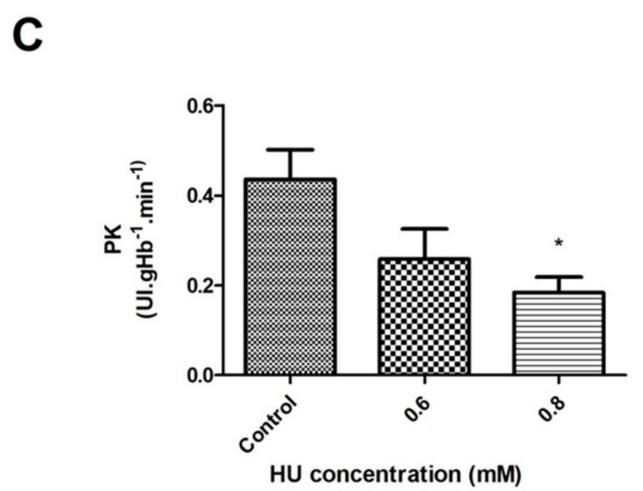

Figure 6. Enzymatic activity of the erythrocyte energy metabolism in the control samples that were treated with 0.6 and $0.8 \mathrm{mM} \mathrm{HU}(n=3)$ for $1 \mathrm{~h}$. Hemolysate was used to measure (A) Glucose-6phosphate-dehydrogenase (G6PD); (B) Hexokinase (Hex); (C) Pyruvate kinase (PK). In all of the cases, * represents a comparison between the control groups and the groups that were treated with HU ( ${ }^{*} p<0.05$ and $\left.{ }^{* * *} p<0.001\right)$, while $\Delta$ represents a comparison between the groups that were treated with 0.6 and $0.8 \mathrm{mM} \mathrm{HU}(p<0.05)$.

Table 1. Comparison of the effects of HU at different concentrations and treatment times on the erythrocytes of healthy individuals when in relation to the control groups.

\begin{tabular}{|c|c|c|c|c|}
\hline \multirow{2}{*}{$\begin{array}{l}\text { Time of Treatment } \\
\text { HU Concentration }\end{array}$} & \multicolumn{2}{|c|}{$30 \mathrm{~min}$} & \multicolumn{2}{|c|}{$1 \mathrm{~h}$} \\
\hline & $0.6 \mathrm{mM}$ & $0.8 \mathrm{mM}$ & $0.6 \mathrm{mM}$ & $0.8 \mathrm{mM}$ \\
\hline \multicolumn{5}{|l|}{ Variables } \\
\hline $\mathrm{Fe}^{3+}$ & $\uparrow$ & $\uparrow$ & - & $\downarrow$ \\
\hline TBARS & - & $\uparrow$ & - & $\downarrow$ \\
\hline $\mathrm{H}_{2} \mathrm{O}_{2}$ & $\uparrow$ & $\uparrow$ & $\uparrow$ & $\uparrow$ \\
\hline SOD & $\uparrow$ & $\uparrow$ & $\uparrow$ & $\uparrow$ \\
\hline CAT & - & - & - & - \\
\hline GPx & $\uparrow$ & $\uparrow$ & $\uparrow$ & $\uparrow$ \\
\hline GR & $\uparrow$ & $\uparrow$ & $\downarrow$ & $\downarrow$ \\
\hline GSH & $\uparrow$ & $\uparrow$ & $\uparrow$ & $\downarrow$ \\
\hline G6PD & $\uparrow$ & $\uparrow$ & $\uparrow$ & $\downarrow$ \\
\hline HEX & $\uparrow$ & $\uparrow$ & - & - \\
\hline PK & $\downarrow$ & - & - & $\downarrow$ \\
\hline
\end{tabular}

TBARS = Thiobarbituric acid reactive substances, SOD = Superoxide dismutase; CAT = Catalase; GPx = Glutathione peroxidase; GR = Glutathione reductase; GSH = Reduced Glutathione; G6PD = Glucose-6-phosphate dehydrogenase; HEX = Hexokinase; PK = Pyruvate kinase; $\uparrow=$ a significant increase; $\downarrow=$ a significant decrease; $-=$ no difference. 
Table 2. Comparison of the data for the different markers when treating the erythrocytes with $0.8 \mathrm{mM}$ versus $0.6 \mathrm{mM} \mathrm{HU}$ for $1 \mathrm{~h}$.

\begin{tabular}{cc}
\hline Concentration & $\mathbf{0 . 8} \mathbf{~ m M}$ \\
\hline $\mathrm{Fe}^{3+}$ & - \\
TBARS & $\downarrow$ \\
$\mathrm{H}_{2} \mathrm{O}_{2}$ & $\downarrow$ \\
SOD & $\downarrow$ \\
CAT & - \\
GPx & - \\
GR & - \\
GSH & $\downarrow$ \\
G6PD & $\downarrow$ \\
HEX & $\downarrow$ \\
PK & - \\
\hline
\end{tabular}

TBARS $=$ Thiobarbituric acid reactive substances, $\mathrm{SOD}=$ Superoxide dismutase $;$ CAT $=$ Catalase $;$ GPx $=$ Glutathione peroxidase; GR = Glutathione reductase; GSH = Reduced Glutathione; G6PD = Glucose-6-phosphate dehydrogenase; HEX = Hexokinase; PK = Pyruvate kinase; $\uparrow=$ a significant increase; $\downarrow$ = a significant decrease; - = no difference.

\section{Discussion}

Hydroxyurea is a drug that is used in the treatment of various diseases, such as cancer and sickle cell anemia, in addition to having a high potential to treat other diseases [29]. In the present in vitro study carried out with the RBC from healthy individuals, changes in these cells were observed after incubations of $0.6 \mathrm{mM}$ and $0.8 \mathrm{mM} \mathrm{HU}$ for 30 and $60 \mathrm{~min}$.

The results showed that after $30 \mathrm{~min}$ of treatment with $\mathrm{HU}$, at both of the concentrations, there was an increase in the $\mathrm{Fe}^{3+}, \mathrm{MDA}$, and $\mathrm{H}_{2} \mathrm{O}_{2}$ levels (Figure $1 \mathrm{~A}-\mathrm{C}$, respectively). According to Iyamu and collaborators [9], after treating the blood in vitro with different concentrations of $\mathrm{HU}$, there was an increase in the oxidation of hemoglobin A and hemoglobin $\mathrm{S}$, the latter of which is present in the patients with sickle cell anemia. The oxidation of hemoglobin leads to the formation of methemoglobin; consequently to the release of $\mathrm{Fe}^{3+}$, contributing to its increase in the plasma [30]. $\mathrm{Fe}^{3+}$ can increase the generation of reactive oxygen species, as well as reacting with the cell membranes, resulting in an increase in lipid peroxidation in both of the cases [31].

MDA is a by-product of the lipid peroxidation of unsaturated phospholipid chains [32], and this increased significantly after $30 \mathrm{~min}$ of treatment with $0.8 \mathrm{mM} \mathrm{HU}$, (Figure 1B). In a previous study that was carried out on Wistar rats, which were treated with different doses of $\mathrm{HU}$, the authors reported an increase in the MDA levels that were caused by the drug, proportional to its concentration [29].

Concerning the $\mathrm{H}_{2} \mathrm{O}_{2}$ content, a significant increase in the treated groups was observed, as seen in Figures $1 \mathrm{C}$ and $2 \mathrm{C}$. Consequently, this can cause the production of other free radicals, such as the hydroxyl radical $(\mathrm{OH} \cdot) . \mathrm{OH}$, when reacting with $\mathrm{Fe}^{3+}$, is one of the most potent oxidants known, and it can accentuate the oxidative stress event $[30,33]$. Huang and collaborators [34], when performing a treatment in yeasts with different concentrations of $\mathrm{HU}$, observed that there was an increase in the levels of the reactive oxygen species (ROS), especially $\mathrm{H}_{2} \mathrm{O}_{2}$. One hypothesis to explain the increase in the concentration of $\mathrm{H}_{2} \mathrm{O}_{2}$ consists of an increase in the activity of the superoxide dismutase enzyme (SOD), as was observed in the present study (Figures $3 \mathrm{~A}$ and 4). This enzyme, which is present in the erythrocyte antioxidant system, was responsible for generating $\mathrm{H}_{2} \mathrm{O}_{2}$ by dismuting the superoxide anion to $\mathrm{H}_{2} \mathrm{O}_{2}$.

It has already been described that $\mathrm{HU}$ also exhibits a greater oxidative potential of hemoglobin when compared to hydrogen peroxide, whilst under the same conditions of drug concentration and time of exposure, as in this current study [9]. This fact reinforces the hypothesis that $\mathrm{HU}$ not only induces an increase in $\mathrm{H}_{2} \mathrm{O}_{2}$ but it is also capable of inducing the formation of other radicals, contributing to a higher oxidation rate. 
After $1 \mathrm{~h}$ of treatment with $0.8 \mathrm{mM}$ HU, the levels of some oxidative stress markers, such as $\mathrm{Fe}^{3+}$ and MDA, decreased significantly when compared to the controls (Figure 2A,B, respectively).

Within this context, it is important to mention another study that also treated the RBC from healthy individuals with potential oxidizing agents, and later with HU. The authors observed that this would have an antioxidant potential since there was a decrease in lipid peroxidation and methemoglobin formation. The finding that HU could react preferably with the radicals formed by such oxidizing agents, would result in protection for the erythrocyte membrane [7]. This data is interesting because it would explain, at least in part, the beneficial effects resulting from the use of $\mathrm{HU}$ in patients with diseases, such as sickle cell anemia, and this drug could contribute to the reduction of free radicals. In 2012, a study by Torres et al. [35] reported a decrease in lipid peroxidation in the patients with sickle cell anemia who used HU when compared to the non-users. Another study that was developed by Brose et al. [36] reported that the treatment of rat neurons with neurotoxic agents, such as $\mathrm{H}_{2} \mathrm{O}_{2}$, and subsequently treated with $\mathrm{HU}$, resulted in a reduction of the neurotoxic stress caused by these agents, as well as inducing an increase in the ATP content in these cells.

When relating the studies above to the current work, we realized that both of the concentrations of $\mathrm{HU}$ that were used for the treatment of the erythrocytes had, at first, an oxidizing effect. Over time, the erythrocyte protection mechanisms seem to be activated, thus reducing the damage to these cells. In diseases where there is natural oxidative stress, such as sickle cell anemia, the patients can be treated with $\mathrm{HU}$, as the use of this drug can benefit those individuals affected by the disease because of its ability to reduce such stress. A study that was carried out with patients with sickle cell anemia, treated or not with HU, observed that the patients that were treated with the drug had a lower number of ROS and greater erythrocyte deformability when compared to the untreated patients [37]. The greater deformability of the RBC can be a favorable effect since such cells would present greater malleability and pass through the capillaries more easily. Despite the significant increase in hydrogen peroxide, the catalase levels did not show significant changes in any of the conditions that were evaluated in this study (Figures 3B and 4B).

The enzymes that are responsible for removing endogenous $\mathrm{H}_{2} \mathrm{O}_{2}$ are peroxiredoxin

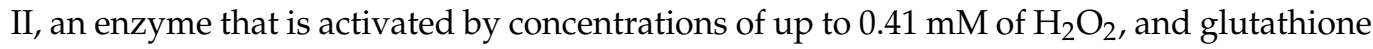
peroxidase, which can reduce $\mathrm{H}_{2} \mathrm{O}_{2}$, as well as the hydroperoxides and peroxynitrites [38]. In this study, the activity of the enzyme GPx was increased at both times of the treatment with $\mathrm{HU}$, which may be related to the increase in $\mathrm{H}_{2} \mathrm{O}_{2}$ that was identified. Corroborating with the findings of this study, Choo et al. [39] demonstrated that a treatment with HU that was induced in the patients with sickle cell anemia, not only increased the GPx activity but also increased its expression.

The authors also observed that the GR activity increased at both of the treatment concentrations after $30 \mathrm{~min}$ (Figure 3D). This finding can be explained by an increase in the GPx activity in all of the samples treated with HU, which generated a greater amount of the substrate (GSSG), culminating in an increase in the activity of glutathione reductase, an enzyme that is responsible for maintaining the GSH levels in the RBC [40]. An increase in the GSH content resulting from the treatment of the two HU concentrations was observed in the current study after 30 min of incubation with the drug (Figure 3E). This finding is in line with the data reported by Teixeira and colleagues [41], who previously described an increase in the GSH that was induced by the treatment with $\mathrm{HU}$ in those patients with sickle cell anemia.

The activity of the G6PD and HEX enzymes was increased in both of the HU concentrations after $30 \mathrm{~min}$ of incubation. This data has suggested that the energy metabolism of the RBC was also stimulated by the presence of $\mathrm{HU}$ during the treatment times (Figure 5A,B). The PK activity was reduced at a concentration of $0.6 \mathrm{mM}$ (Figure $5 \mathrm{C}$ ), indicating that the pentose phosphate pathway was preferably more active under these conditions. 
The fact that the pentose pathway was preferably active, instead of the glycolytic pathway, could explain the increase in $\mathrm{Fe}^{3}+$ that was found by the authors (Figure 1A) after the treatment with HU for $30 \mathrm{~min}$. The NADH that was produced in this pathway was not available for use by the enzyme, cytochrome-b5 reductase, which is responsible for most of the interconnection of $\mathrm{Fe}^{3}+$ to $\mathrm{Fe}^{2+}$ (methemoglobin to hemoglobin) in the RBC.

The increased activity of HEX produced glucose-6-phosphate, a substrate for the G6PD enzyme, which plays an important role in the antioxidant system of the RBC since it produces NADPH [42], which is a cofactor for the production of GSH, one of the most important non-enzymatic antioxidants in the RBC. GSH was responsible for helping to protect the membranes against the superoxides, as well as other types of reactive oxygen species $[40,43]$.

The induction of an increase in the G6PD activity was an important effect of HU since patients with sickle cell anemia have a restricted flow of NADPH. At low oxygen tensions, $\mathrm{HbS}$ binds very strongly to the cytoplasmic domain of band 3, a protein that is responsible for regulating glycolysis. Thus, the enzymes of the glycolytic pathway that are linked to the cytoplasmic domain of band 3 (phosphofructokinase and glyceraldehyde-3-phosphate dehydrogenase), remain in the cytoplasm, creating competition between the glycolytic and pentose pathways for the substrate (glucose- 6-phosphate), restricting the formation of NADPH [44]. In sickle cell anemia, the greater the release of the ROS, the stronger is the link between the cytoplasmic domain of band $3, \mathrm{HbS}$, and the hemicromes that are formed by the denaturation of hemoglobin. Increased G6PD activities enhance the production of NADPH and this might help to lessen the clinical effects caused by sickle cell anemia.

After the exposure of the RBC to HU for $1 \mathrm{~h}$, a decrease in the GR activity was observed (Figure 4D) at the 0.6 and $0.8 \mathrm{mM} \mathrm{HU}$ concentrations, while there was an increase in the GSH content with $0.6 \mathrm{mM}$, followed by a decrease of this enzyme when using $0.8 \mathrm{mM}$ of the drug (Figure 4E). In a previous study by this current group, a reduction of about $41 \%$ in the GSH content and 17\% in the GR activity was observed in the blood samples from the patients with sickle cell anemia when treated with HU, compared to the patients who did not use this medicine [45].

These results might be explained by the reduction in the GSH levels and the activity of the enzyme G6PD, which was responsible for the production of NADPH (cofactor for GR) in the concentration of $0.8 \mathrm{mM} \mathrm{HU}$; consequently, this would decrease the activity of the GR. In addition, the enzyme saturation might also explain the decreased activity of this enzyme. The G6PD might have had a decreased activity because there was no increase in the production of its substrate (glucose-6-phosphate) by the enzyme hexokinase, which remained without significant changes (Figure 6B) between the controls and those treated with HU.

Raththagala et al. [46] reported a significant increase in the ATP release in the HUtreated rabbit RBC after $20 \mathrm{~min}$, due to the induction of greater RBC deformability. In these circumstances, the greater release of ATP could indicate a greater functioning of the enzymes in the glycolytic pathway. In this study, the authors did not find significant differences in the activity of the hexokinase enzyme after $1 \mathrm{~h}$ of incubation with $0.8 \mathrm{mM}$ $\mathrm{HU}$, although there was a reduction in the activity of pyruvate kinase at this concentration (Figure 6C). This data corroborates the possible inactivation of the glycolytic pathway under these conditions and that it was also reduced after the treatment with $\mathrm{HU}$ for $30 \mathrm{~min}$. This has allowed the authors to infer that the treatments with HU most likely preferentially stimulated the pentose pathway and not the glycolytic pathway.

The $\mathrm{Fe}^{3}+$ content did not change significantly at the concentration of $0.6 \mathrm{mM} \mathrm{HU}$ when in relation to the controls, and it decreased when compared to the treatment with $0.8 \mathrm{mM} \mathrm{HU}$. This result allows the authors to suggest that the increase in the activity of the enzyme, NADPH-methemoglobin reductase, helped in the process of converting $\mathrm{Fe}^{3}+$ to $\mathrm{Fe}^{2+}$ (methemoglobin to hemoglobin). The decrease in the content of $\mathrm{Fe}^{3}+$ might mean that the index of the reactive oxygen species decreased, as well as the oxidation of hemoglobin since a decrease in lipid peroxidation at a concentration of $0.8 \mathrm{mM}$ was also identified. 
When comparing the data that was obtained from the RBC that were treated with HU at concentrations of 0.6 and $0.8 \mathrm{mM}$ after $1 \mathrm{~h}$, it can be assumed that the latter concentration appeared to be more efficient in the fight against the free radicals. The experimental condition of the RBC that was incubated for $1 \mathrm{~h}$ with $0.8 \mathrm{mM} H U$ was able to reduce the levels of the oxidative stress markers (hydrogen peroxide and lipid peroxidation-Figure 2B,C). It is also worth noting that $0.8 \mathrm{mM} \mathrm{HU}$ was the only dose capable of decreasing the $\mathrm{Fe}^{3+}$ content when compared with the control groups (Figure 2A).

Another interesting change when comparing both of the HU concentrations that were used in this study was the significant decrease in the SOD activity. This reduction, which was associated with the decrease in the concentration of $\mathrm{Fe}^{3}+$, allows the authors to infer that the oxidation process of hemoglobin decreased at the concentration of $0.8 \mathrm{mM} \mathrm{HU}$ after $1 \mathrm{~h}$ of incubation since $\mathrm{Fe}^{3+}$ and the superoxide anion (substrate for SOD) were products of the $\mathrm{Hb}$ oxidation $[47,48]$.

It is important to highlight the difference that was identified between the HU concentrations that were used in this study. The activities of the HEX and G6PD enzymes (Figure 6A,B) and the GSH content (Figure 4E) decreased when the RBC were incubated with $0.8 \mathrm{mM}$ when compared to $0.6 \mathrm{mM} \mathrm{HU}$. Two hypotheses are to be considered: (1) the enzymatic saturation during the process of protection against the ROS. GR, which produces GSH, did not have the necessary cofactor (NADPH) produced by G6PD, which in turn required the production of glucose-6-phosphate by hexokinase to function; (2) the amount of the reactive oxygen species decreased in the presence of $0.8 \mathrm{mM}$ of HU so that the production of GSH and NADPH was not stimulated, a fact that was confirmed by the decrease in lipid peroxidation (Figure 6B). The differences between the results obtained by the two HU concentrations $(0.6$ and $0.8 \mathrm{mM})$ have led the authors to reflect on what would be the best dose to be used by the patients with diseases of which HU is a part of the therapeutic scheme. In diseases, such as sickle cell anemia, in which the existence of oxidative stress is one of the main causes related to the clinical symptoms, the dose of $0.8 \mathrm{mM}$ might have a better effect on the antioxidant system and the production of ROS; consequently, reducing the oxidative stress and therefore, benefiting the patients.

Although this study was carried out with the RBC from healthy individuals, the changes described in this study might help to elucidate the mechanisms of action of HU when administered for therapeutic purposes for certain diseases. The evidence in the literature indicates that the study's results are similar to those reported in other studies that involve the treatment with HU, as in sickle cell anemia.

The effects of HU in those patients with sickle cell anemia go far beyond the increase in $\mathrm{HbF}$ and the decrease in cell production by the bone marrow. Further studies are still needed to understand other possible effects of using this drug on the RBC and whether these effects are harmful or not for the patient. The data presented in this paper raises the need for further investigations, to expand the effects of HU through other laboratory markers, opening perspectives for future studies. As an example, a more in-depth study of the HU effects on the composition and modulation of the RBC membranes can be suggested.

Author Contributions: Conceptualization, M.d.B.P., D.R.A.R., V.F.C., L.A.d.O.B., H.d.L.S. and C.O.R.; methodology, M.d.B.P., D.R.A.R., V.F.C., L.A.d.O.B., H.d.L.S. and C.O.R.; analysis, C.O.R.; resources, M.d.B.P., V.F.C., L.A.d.O.B. and H.d.L.S.; data curation, M.d.B.P., V.F.C., L.A.d.O.B. and H.d.L.S.; writing-original draft preparation, C.O.R., G.A.S.M. and L.S.N.; writing-review and editing, M.d.B.P., V.F.C., L.A.d.O.B., H.d.L.S., D.R.A.R., G.A.S.M., H.d.L.S. and C.O.R.; supervision, H.d.L.S.; funding acquisition, M.d.B.P., V.F.C., L.A.d.O.B., H.d.L.S., D.R.A.R. All authors have read and agreed to the published version of the manuscript.

Funding: This study was financed in part by the Coordenação de Aperfeiçoamento de Pessoal de Nível Superior-Brasil (CAPES)-Finance Code 001, FAPEMIG (Fundação de Amparo à Pesquisa do Estado de Minas Gerais) APQ-00855-19, and National Council for Scientific and Technological Development-CNPq 305173/2018-9. 
Institutional Review Board Statement: The study was conducted according to the guidelines of the Declaration of Helsinki, and approved by the Ethics Committee on Human Research of the Federal University of São João del Rei, Brazil (n 2.977.566/2018).

Informed Consent Statement: Informed consent was obtained from all of the subjects involved in the study.

Data Availability Statement: Data is contained within the article.

Acknowledgments: The authors are thankful to Maria das Graças Carvalho (UFSJ) for the helpful evaluation of the manuscript.

Conflicts of Interest: The authors declare no conflict of interest.

\section{References}

1. Kovacic, P. Hydroxyurea (therapeutics and mechanism): Metabolism, carbamoyl nitroso, nitroxyl, radicals, cell signaling, and clinical applications. Med. Hypotheses 2011, 76, 24-31. [CrossRef]

2. Agrawal, R.K.; Patel, R.K.; Shah, V.; Nainiwal, L.; Trivedi, B. Hydroxyurea in sickle cell disease: Drug review. Indian J. Hematol. Blood Transfus. 2014, 30, 91-96. [CrossRef] [PubMed]

3. Legrand, T.; Rakotoson, M.G.; Galacteros, F.; Bartolucci, P.; Hulin, A. Determination of hydroxyurea in human plasma by HPLC-UV using derivatization with xanthydrol. J. Chromatogr. B Anal. Technol. Biomed. Life Sci. 2017, 1064, 85-91. [CrossRef]

4. Navarra, P.; Preziosi, P. Hydroxyurea: New insights on an old drug. Crit. Rev. Oncol. Hematol. 1999, 29, 249-255. [CrossRef]

5. Tracewell, W.G.; Trump, D.L.; Vaughan, W.P.; Smith, D.C.; Gwilt, P.R. Population pharmacokinetics of hydroxyurea in cancer patients. Cancer Chemother. Pharmacol. 1995, 35, 417-422. [CrossRef]

6. Walker, A.L.; Franke, R.M.; Sparreboom, A.; Ware, R.E. Transcellular movement of hydroxyurea is mediated by specific solute carrier transporters. Exp. Hematol. 2011, 39, 446-456. [CrossRef] [PubMed]

7. Agil, A.; Sadrzadeh, S.M.H. Hydroxy-urea protects erythrocytes against oxidative damage. Redox Rep. 2000, 5, 29-34. [CrossRef]

8. Malec, J.; Przybyszewski, W.M.; Grabarczyk, M.; Sitarska, E. Hydroxyurea has the capacity to induce damage to human erythrocytes, which can be modified by radical scavengers. Biochem. Biophys. Res. Commun. 1984, 120, 566-573. [CrossRef]

9. Iyamu, E.W.; Fasold, H.; Roa, D.; del Pilar Aguinaga, M.; Asakura, T.; Turner, E.A. Hydroxyurea-induced oxidative damage of normal and sickle cell hemoglobins in vitro: Amelioration by radical scavengers. J. Clin. Lab. Anal. 2001, 15, 1-7. [CrossRef]

10. Lorenzi, T.F. Manual of Propaedeutic and Clinical Hematology, 4th ed.; Guanabara Koogan: Rio de Janeiro, Brazil, 2006.

11. Thom, C.S.; Dickson, C.F.; Gell, D.A.; Weiss, M.J. Hemoglobin variants: Biochemical properties and clinical correlates. Cold Spring Harb. Perspect. Med. 2013, 3, a011858. [CrossRef]

12. Luzzatto, L.; Nannelli, C.; Notaro, R. Glucose-6-Phosphate Dehydrogenase Deficiency. Hematol. Oncol. Clin. N. Am. 2016, 30, 373-393. [CrossRef]

13. Arbos, K.A.; Claro, L.M.; Borges, L.; Santos, C.A.; Weffort-Santos, A.M. Human erythrocytes as a system for evaluating the antioxidant capacity of vegetable extracts. Nutr. Res. 2008, 28, 457-463. [CrossRef] [PubMed]

14. Petit, K.; Suwalsky, M.; Colina, J.R.; Contreras, D.; Aguilar, L.F.; Jemiola-Rzeminska, M.; Strzalka, K. Toxic effects of the anticancer drug epirubicin in vitro assayed in human erythrocytes. Toxicol. In Vitro 2020, 68, 104964. [CrossRef]

15. Morabito, R.; Romano, O.; La Spada, G.; Marino, A. $\mathrm{H}_{2} \mathrm{O}_{2}$-Induced Oxidative Stress Affects $\mathrm{SO}_{4}=$ Transport in Human Erythrocytes. PLoS ONE 2016, 11, e0146485. [CrossRef]

16. Dacie, J.V.; Lewis, S.M. Pratical Hematology, 8th ed.; Churchill Livingstone: Edinburgh, UK, 1996.

17. Atmaca, G. Antioxidant effects of sulfur-containing amino acids. Yonsei Med. J. 2004, 45, 776-788. [CrossRef] [PubMed]

18. Costa, C.M.; Santos, R.C.C.; Lima, E.S. A simple automated procedure for thiol measurement in human serum samples. J. Bras. Patol. Med. Lab. 2006, 42, 345-350. [CrossRef]

19. Adams, P.E. Determining Iron Content in Foods by Spectrophotometry. J. Chem. Educ. 1995, 72, 649-651. [CrossRef]

20. Jiang, Z.Y.; Woollard, A.C.; Wolff, S.P. Hydrogen peroxide production during experimental protein glycation. FEBS Lett. 1990, 268, 69-71. [CrossRef]

21. Misra, H.P.; Fridovich, I. The role of superoxide anion in the autoxidation of epinephrine and a simple assay for superoxide dismutase. J. Biol. Chem. 1972, 247, 3170-3175. [CrossRef]

22. Aebi, H. Catalase in vitro. Methods Enzymol. 1984, 105, 121-126. [CrossRef]

23. Flohe, L.; Gunzler, W.A.; Schock, H.H. Glutathione peroxidase: A selenoenzyme. FEBS Lett. 1973, 32, 132-134. [CrossRef]

24. Nakamura, W.; Hosoda, S.; KazukoHayashib, K. Purification, and the properties of rat liver glutathione peroxidase. Biochim. Biophys. Acta 1974, 358, 251-261. [CrossRef]

25. Beutler, E.; Duron, O.; Kelly, B.M. An improved method for the determination of blood glutathione. J. Lab. Clin. Med. 1963, 61, 882-888.

26. Jollow, D.J.; Mitchell, J.R.; Zampaglione, N.; Gillette, J.R. Bromobenzene-induced liver necrosis. Protective role of glutathione and evidence for 3,4-bromobenzene oxide as the hepatotoxic metabolite. Pharmacology 1974, 11, 151-169. [CrossRef] [PubMed]

27. Racker, E. Glutathione reductase from bakers' yeast and beef liver. J. Biol. Chem. 1955, 217, 855-865. [CrossRef]

28. Beutler, E. Red Cell Metabolism: A Manual of Biochemical Methods, 3rd ed.; Grune e Stratton: New York, NY, USA, 1984. 
29. Ahmad, M.F.; Ansari, M.O.; Jameel, S.; Wani, A.L.; Parveen, N.; Siddique, H.R.; Shadab, G. Protective role of nimbolide against chemotherapeutic drug hydroxyurea induced genetic and oxidative damage in an animal model. Environ. Toxicol. Pharmacol. 2018, 60, 91-99. [CrossRef] [PubMed]

30. Tsantes, A.E.; Bonovas, S.; Travlou, A.; Sitaras, N.M. Redox imbalance, macrocytosis, and RBC homeostasis. Antioxid. Redox Signal. 2006, 8, 1205-1216. [CrossRef]

31. Belcher, J.D.; Beckman, J.D.; Balla, G.; Balla, J.; Vercellotti, G. Heme degradation and vascular injury. Antioxid. Redox Signal. 2010, 12, 233-248. [CrossRef]

32. Benzie, I.F. Lipid peroxidation: A review of causes, consequences, measurement, and dietary influences. Int. J. Food Sci. Nutr. 1996, 47, 233-261. [CrossRef]

33. Rocha, S.; Gomes, D.; Lima, M.; Bronze-da-Rocha, E.; Santos-Silva, A. Peroxiredoxin 2, glutathione peroxidase, and catalase in the cytosol and membrane of erythrocytes under $\mathrm{H}_{2} \mathrm{O}_{2}$-induced oxidative stress. Free Radic. Res. 2015, 49, 990-1003. [CrossRef]

34. Huang, M.E.; Facca, C.; Fatmi, Z.; Baille, D.; Benakli, S.; Vernis, L. DNA replication inhibitor hydroxyurea alters Fe-S centers by producing reactive oxygen species in vivo. Sci. Rep. 2016, 6, 29361. [CrossRef]

35. Torres, L.S.; Silva, D.G.H.; Belini Junior, E.; Almeida, E.A.; Lobo, C.L.C.; Cancado, R.D.; Ruiz, M.A.; Bonini-Domingos, C.R. The influence of hydroxyurea on oxidative stress in sickle cell anemia. Rev. Bras. Hematol. Hemoter. 2012, 34, 421-425. [CrossRef]

36. Brose, R.D.; Lehrmann, E.; Zhang, Y.; Reeves, R.H.; Smith, K.D.; Mattson, M.P. Hydroxyurea attenuates oxidative, metabolic, and excitotoxic stress in rat hippocampal neurons and improves spatial memory in a mouse model of Alzheimer's disease. Neurobiol. Aging 2018, 72, 121-133. [CrossRef] [PubMed]

37. Nader, E.; Grau, M.; Fort, R.; Collins, B.; Cannas, G.; Gauthier, A.; Walpurgis, K.; Martin, C.; Bloch, W.; Poutrel, S.; et al. Hydroxyurea therapy modulates sickle cell anemia red blood cell physiology: Impact on RBC deformability, oxidative stress, nitrite levels, and nitric oxide synthase signaling pathway. Nitric Oxide 2018, 81, 28-35. [CrossRef]

38. Rhee, S.G.; Chae, H.Z.; Kim, K. Peroxiredoxins: A historical overview and speculative preview of novel mechanisms and emerging concepts in cell signaling. Free Radic. Biol. Med. 2005, 38, 1543-1552. [CrossRef] [PubMed]

39. Cho, C.S.; Kato, G.J.; Yang, S.H.; Bae, S.W.; Lee, J.S.; Gladwin, M.T.; Rhee, S.G. Hydroxyurea-induced expression of glutathione peroxidase 1 in red blood cells of individuals with sickle cell anemia. Antioxid. Redox Signal. 2010, 13, 1-11. [CrossRef] [PubMed]

40. Kurata, M.; Suzuki, M.; Agar, N.S. Antioxidant systems and erythrocyte life span in mammals. Comp. Biochem. Physiol. B 1993, 106, 477-487. [CrossRef]

41. Teixeira Neto, P.F.; Gonçalves, R.P.; Elias, D.B.D.; Araújo, C.P.; Magalhães, H.I.F. Analysis of oxidative status and biochemical parameters in adult patients with sickle cell anemia treated with hydroxyurea, Ceará, Brazil. Rev. Bras. Hematol. Hemoter. 2011, 33, 207-210. [CrossRef]

42. Van Zwieten, R.; Verhoeven, A.J.; Roos, D. Inborn defects in the antioxidant systems of human red blood cells. Free Radic. Biol. Med. 2014, 67, 377-386. [CrossRef]

43. Kalpakcioglu, B.; Senel, K. The interrelation of glutathione reductase, catalase, glutathione peroxidase, superoxide dismutase, and glucose-6-phosphate in the pathogenesis of rheumatoid arthritis. Clin. Rheumatol. 2008, 27, 141-145. [CrossRef] [PubMed]

44. Rogers, S.C.; Ross, J.G.; d'Avignon, A.; Gibbons, L.B.; Gazit, V.; Hassan, M.N.; McLaughlin, D.; Griffin, S.; Neumayr, T.; Debaun, M.; et al. Sickle hemoglobin disturbs normal coupling among erythrocyte $\mathrm{O}_{2}$ content, glycolysis, and antioxidant capacity. Blood 2013, 121, 1651-1662. [CrossRef] [PubMed]

45. Reno, C.O.; Barbosa, A.R.; de Carvalho, S.S.; Pinheiro, M.B.; Rios, D.R.; Cortes, V.F.; Barbosa, L.A.; Santos, H.L. Oxidative stress assessment in sickle cell anemia patients treated with hydroxyurea. Ann. Hematol. 2020, 99, 937-945. [CrossRef] [PubMed]

46. Raththagala, M.; Karunarathne, W.; Kryziniak, M.; McCracken, J.; Spence, D.M. Hydroxyurea stimulates the release of ATP from rabbit erythrocytes through an increase in calcium and nitric oxide production. Eur. J. Pharmacol. 2010, 645, 32-38. [CrossRef]

47. Naoum, P.C.; Radispiel, J.; Moraes, M.S. Methaemoglobin spectrometric dosage without chemical or enzymatic interferers. Rev. Bras. Hematol. Hemoter. 2004, 26, 9-22.

48. Cimen, M.Y. Free radical metabolism in human erythrocytes. Clin. Chim. Acta 2008, 390, 1-11. [CrossRef] [PubMed] 